\title{
ANALISIS PENJADWALAN PROYEK GEDUNG BERTINGKAT DENGAN METODE PERT DAN M-PERT MENGGUNAKAN SIMULASI MONTE CARLO
}

\author{
Josua Guntur Putra ${ }^{1}$ dan Jane Sekarsari ${ }^{2}$ \\ ${ }^{1}$ Program Studi Sarjana Teknik Sipil, Universitas Tarumanagara, Jl. Letjen S. Parman No.1 Jakarta \\ josua.325160153@stu.untar.ac.id \\ ${ }^{2}$ Program Studi Sarjana Teknik Sipil, Universitas Tarumanagara, Jl. Letjen S. Parman No.1 Jakarta \\ tamtana.js@gmail.com
}

\begin{abstract}
One of the keys to success in construction execution is timeliness. In fact, construction is often late than originally planned. It's caused by project scheduling uncertainty. Deterministic scheduling methods use data from previous projects to determine work duration. However, not every project has same work duration. The PERT method provides a probabilistic approach that can overcome these uncertainties, but it doesn't account for the increase in duration due to parallel activities. In 2017, the PERT method was developed into the M-PERT method. The purpose of this study is to compare the mean duration and standard deviation of the overall project between PERT and MPERT methods and compare them in Monte Carlo simulation. The research method used is to calculate the mean duration of the project with the PERT, M-PERT, and Monte Carlo simulation. The study was applied to a threestory building project. From the results of the study, the standard deviation obtained was 5.079 for the M-PERT method, 8.915 for the PERT method, and 5.25 for the Monte Carlo simulation. These results show the M-PERT method can provide closer results to computer simulation result than the PERT method. Small standard deviation value indicates the M-PERT method gives more accurate results.
\end{abstract}

Keywords: Uncertainty; PERT; M-PERT; Monte Carlo Simulation

\begin{abstract}
ABSTRAK
Salah satu kunci keberhasilan dalam suatu pelaksanaan konstruksi adalah ketepatan waktu. Kenyataannya, pelaksanaan konstruksi sering mengalami keterlambatan waktu dari yang direncanakan. Hal ini disebabkan oleh ketidakpastian dalam merencanakan penjadwalan proyek. Metode penjadwalan yang bersifat deterministik menggunakan data dari proyek sebelumnya untuk menentukan durasi pekerjaan. Akan tetapi, tidak setiap proyek memiliki durasi pekerjaan yang sama. Metode PERT memberikan pendekatan probabilistik yang dapat mengatasi ketidakpastian tersebut, tetapi metode ini tidak memperhitungkan pertambahan durasi akibat adanya kegiatan yang berbentuk paralel. Pada tahun 2017, metode PERT dikembangkan menjadi metode M-PERT. Tujuan dari penelitian ini adalah membandingkan mean durasi dan standar deviasi proyek secara keseluruhan antara metode PERT dan MPERT dan membandingkan kedua metode tersebut dalam simulasi Monte Carlo. Metode penelitian yang dilakukan adalah menghitung mean durasi proyek dengan metode PERT, M-PERT, dan simulasi Monte Carlo. Penelitian diterapkan pada proyek gedung bertingkat tiga. Dari hasil penelitian, nilai standar deviasi diperoleh sebesar 5,079 untuk metode M-PERT, 8,915 untuk metode PERT, dan 5,25 untuk simulasi Monte Carlo. Hasil ini menunjukan metode M-PERT dapat memberikan hasil yang lebih mendekati hasil simulasi komputer daripada metode PERT. Nilai standar deviasi yang kecil menunjukan metode M-PERT memberikan hasil yang lebih akurat.
\end{abstract}

Kata kunci: Ketidakpastian; PERT; M-PERT; Simulasi Monte Carlo

\section{PENDAHULUAN}

Salah satu kunci keberhasilan dalam suatu pelaksanaan konstruksi adalah ketepatan waktu. Akan tetapi, seringkali pelaksanaan konstruksi mengalami keterlambatan waktu dan terkadang melewati durasi proyek yang direncanakan. Hal ini disebabkan oleh adanya ketidakpastian dalam merencanakan penjadwalan proyek. Ada beberapa teknik dasar manajemen proyek yang digunakan dalam bentuk perencanaan jaringan (network planning), yaitu Critical Path Method (CPM), Precendence Diagram Method (PDM) dan Program Evaluation and Review Technique (PERT). CPM dan PDM merupakan metode penjadwalan yang memperkirakan waktu kegiatan yang bersifat deterministik. Praktisi menggunakan data pelaksanaan pekerjaan dari proyek sebelumnya dan pengalaman untuk menentukan 
durasi pekerjaan. Akan tetapi, dalam pelaksanaannya seringkali tidak berjalan sesuai dengan perencanaan awal. Setiap proyek tidak akan selalu sama dengan proyek-proyek yang lain (PMI, 2017).

PERT merupakan metode penjadwalan yang melakukan pendekatkan waktu kegiatan yang bersifat probabilistik. Pendekatan ini mengestimasi durasi proyek pada kondisi di mana terdapat ketidakpastian pada durasi aktivitasnya. Namun masih terdapat kekurangan yang perlu diatasi dalam metode PERT, yaitu tidak memperhitungkan bertambahnya durasi akibat banyaknya kegiatan yang berbentuk parallel (Ballesteros-Pérez, 2017).

Pada tahun 2017, Ballesteros-Pérez melakukan sebuah penelitian mengenai pengembangan dari metode PERT, yang dikenal dengan sebutan M-PERT. Pada metode M-PERT, diagram jaringan kerja disederhanakan dengan cara menggabungkan dua atau lebih aktivitas yang ada menjadi sebuah aktivitas baru (merger). Proses tersebut dilakukan berulang sampai tersisa satu aktivitas yang mewakili durasi total proyek secara keseluruhan. Kelebihan dari metode M-PERT adalah dapat mengatasi kegiatan yang berbentuk parallel sehingga presentase kesalahan pada varians dapat diperkecil (Ballesteros-Pérez, 2017).

Berdasarkan penjabaraan pada latar belakang, penulis ingin mencoba membuktikan pernyataan Ballesteros-Pérez dengan membandingkan durasi dan standar deviasi metode PERT dan metode M-PERT pada perencanaan penjadwalan proyek. Kemudian kedua metode tersebut dibandingkan dalam simulasi Monte Carlo untuk mengetahui seberapa besar tingkat kepastian dalam menentukan durasi proyek. Simulasi Monte Carlo dijalankan menggunakan program Full Monte pada Microsoft Project.

\section{Metode PERT}

Project Evaluation and Review Technique (PERT) adalah sebuah model Management Science untuk perencanaan dan pengendalian sebuah proyek (Siswanto, 2007). Teknik PERT adalah suatu metode yang bertujuan untuk mengurangi adanya penundaan, maupun gangguan produksi, serta mengkoordinasikan berbagai bagian suatu pekerjaan secara menyeluruh dan mempercepat selesainya proyek. Teknik ini memungkinkan untuk menghasilkan suatu pekerjaan yang terkendali dan teratur, karena jadwal dan anggaran dari suatu pekerjaan telah ditentukan terlebih dahulu sebelum dilaksanakan. Tujuan dari PERT adalah suatu pencapaian dimana waktu merupakan dasar penting dari PERT dalam penyelesaian kegiatan suatu proyek (Jay Heizer \& Barry Render, 2005).

Menurut Jay Heizer \& Barry Render (2005), jaringan PERT ditetapkan dalam tiga perkiraan waktu (three times estimates) untuk masing-masing jaringan aktivitas. Three times estimates meliputi:

1. Waktu optimis (a): waktu terpendek kejadian yang mungkin terjadi. Waktu yang dibutuhkan oleh sebuah kegiatan jika semua hal berlangsung sesuai rencana.

2. Waktu pesimis (b): waktu terpanjang kejadian yang dibutuhkan. Waktu yang dibutuhkan suatu kegiatan dengan asumsi kondisi yang ada sangat tidak diharapkan.

3. Waktu realistis (m): waktu yang paling memungkinkan terjadi untuk penyelesaian aktivitas dalam jaringan PERT, merupakan waktu yang paling sering terjadi jika suatu aktivitas diulang beberapa kali.

Peluang terjadinya ketiga jenis waktu ini digambarkan pada gambar 1 dalam bentuk distribusi normal.

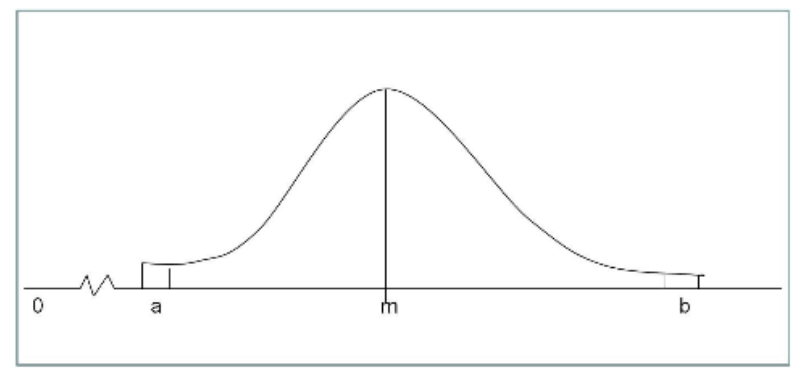

Gambar 1. Tiga perkiraan waktu pada PERT (Sumber: Siswanto, 2007)

Ketiga nilai perkiraan waktu tersebut, yaitu a, b, m, dihubungkan menjadi satu nilai yang disebut expected return (Te). Nilai tersebut merupakan nilai mean jika kejadian tersebut dikerjakan berulang dalam jumlah besar.

Nilai expected return (Te) dapat diperoleh pada persamaan:

$$
\mathrm{Te}=\frac{\mathrm{a}+4 \mathrm{~m}+\mathrm{b}}{6}
$$

dengan $\mathrm{a}=$ waktu optimis, $\mathrm{m}=$ waktu realistis, $\mathrm{b}=$ waktu pesimis . 
Dengan menggunakan konsep te, maka jalur kritis dapat diidentifikasi. Pada jalur kritis berlaku slack = 0 (Soeharto, 1999). Rentang waktu pada tiga nilai estimasi PERT menandai derajat ketidakpastian dalam estimasi kurun waktu. Besarnya ketidakpastian tergantung pada besarnya angka a dan b, dirumuskan sebagai berikut:

Deviasi standar kegiatan (S):

$$
S=\frac{1}{6}(b-a)
$$

Varians kegiatan V(te):

$$
V(\text { te })=S^{2}=\left(\frac{b-a}{6}\right)^{2}
$$

\section{Metode M-PERT}

Metode M-PERT merupakan pengembangan dari metode PERT konvensional. Metode M-PERT ini dikembangkan oleh Pablo Ballesteros-Pérez, Ph.D. Seorang pengajar di School of Construction Management and Engineering, University of Reading, Inggris. M-PERT ini dikembangkan berdasarkan pada lima penelitian terdahulu yaitu penelitian oleh Pritsker (1996), Sculli dan Schum (1991), Gong dan Hugsted (1993), Cox (1995), dan Mehrotra et. Al. (1996) yang sebagian besar memberikan beberapa ciri tertentu (Ballesteros- Pérez, 2017).

Metode PERT dan M-PERT memiliki kesamaan dimana keduanya menentukan durasi proyek secara manual. Keduanya juga memberikan kondisi dimana hubungan antara 2 aktivitas dalam jaringan kerja hanyalah finish-tostart. Perbedaan antara kedua metode ini terletak pada jenis jaringan kerjanya. Pada metode PERT, jaringan kerjanya menggunakan diagram Activity on Arrow (AoA), sedangkan metode M-PERT menggunakan diagram Activity on Node (AoN). Metode M-PERT menggunakan Activity on Node karena lebih mudah digunakan oleh praktisi dan lebih umum ditemukan dalam perangkat lunak (misalnya, Microsoft Project, Oracle Primavera). Oleh karena seluruh hubungan antar aktivitas pada metode M-PERT harus berupa finish-start, maka bentuk hubungan selain finish-start harus dikonversi menjadi finish-start (Ballesteros- Pérez, 2017).

Pada dasarnya, M-PERT adalah teknik reduksi di mana kegiatan proyek digabung oleh grup yang terdiri dari dua atau lebih kegiatan, yang pada akhirnya menghasilkan satu kegiatan gabungan baru. Proses ini diulang sampai hanya ada satu kegiatan yang tersisa, yang mewakili durasi proyek total. Prosedur penggabungan ini diusulkan oleh Cox (1995) sebagai pendekatan yang relatif cepat untuk mengurangi jaringan kompleks menjadi lebih sederhana (Ballesteros- Pérez, 2017).

\section{Konversi hubungan aktivitas pada M-PERT}

Berbeda dengan diagram kerja Activity on Arrow (AoA) yang hanya memiliki satu jenis hubungan precedence (finish-start), Activity on Node (AoN) memiliki 4 jenis hubungan precedence. Keempat jenis hubungan tersebut adalah: finish-to-start (FS), start-to-start (SS), start-to-finish (SF), dan finish-to-finish (FF).

Selain hubungan finish-start, ketiga jenis hubungan precedence lainnya dapat terjadi, akan tetapi dapat mempersulit visualisasi jaringan dan jalur kritis saat jumlah kegiatan sangat banyak. Hal tersebut disebabkan beberapa anak panah meninggalkan node dari belakangnya dan / atau mencapai node didepannya. Berdasarkan Lu dan Lam (2009) dalam Ballesteros-Peréz (2017), ketiga jenis precedence ini dapat diformulasikan ulang menjadi hubungan finish-start, seperti yang ditunjukkan pada Tabel 1. Oleh karena itu, metode M-PERT menggunakan jaringan Activity on Node dengan hubungan antar aktivitasnya finish-start.

Tabel 1. Jenis hubungan precedence dalam M-PERT

\begin{tabular}{lll}
\hline Tipe precedence & Hubungan dalam diagram AoN Konversi menjadi finish-start \\
\hline Finish-Start $(\mathrm{FS})$ & Start-Start $(\mathrm{SS})$
\end{tabular}


Tabel 1. Jenis hubungan precedence dalam M-PERT (lanjutan)

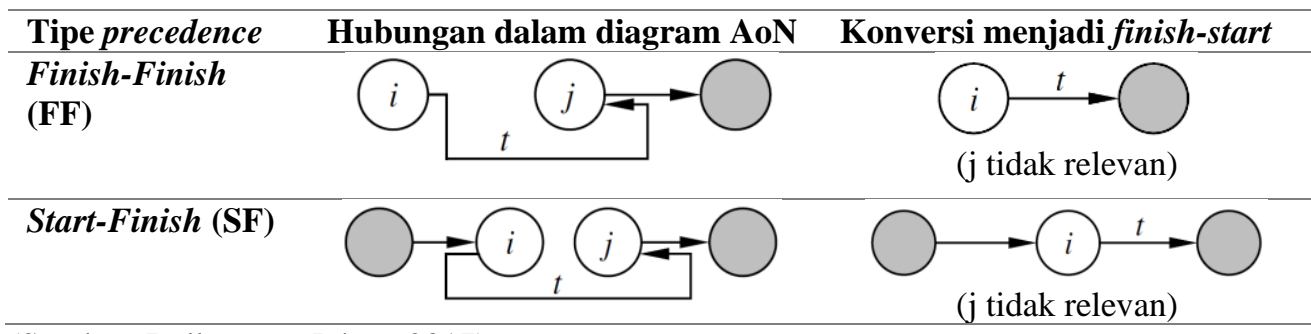

(Sumber: Ballesteros-Pérez, 2017)

\section{Penggabungan aktivitas (Merging)}

Ada terdapat 4 jenis kegiatan, yaitu kegiatan seri, jalur alternatif, self-loop, jalur paralel. Masing-masing kegiatan ini menggunakan rumus yang berbeda untuk menggabungkan kegiatan tersebut. Hasil dari penggabungan ini akan menjadi kegiatan baru baru yang mewakili kegiatan-kegiatan yang digabung sebelumnya. Rumus penggabungan dapat dilihat pada tabel 2.

Tabel 2. Rumus penggabungan aktivitas pada M-PERT

Operasi

nilai maksimum:

$$
\mu_{\mathrm{k}}=\mu_{\mathrm{i}} \Phi(\delta)+\mu_{\mathrm{j}}(1-\Phi(\delta))+\theta \varphi(\delta)
$$

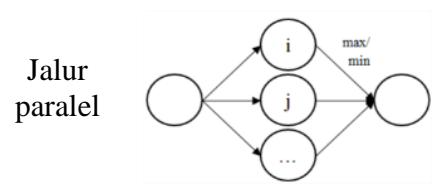

$$
\begin{gathered}
\mu_{\mathrm{i}}, \sigma_{\mathrm{i}}^{2} \\
\mu_{\mathrm{j}}, \sigma_{\mathrm{j}}^{2} \\
\rho(\mathrm{jika} \mathrm{i} \& \mathrm{j} \\
\text { berkorelasi, } \\
\text { sebaliknya }
\end{gathered}
$$

$$
\sigma_{\mathrm{k}}^{2}=\left(\sigma_{\mathrm{i}}^{2}+\mu_{\mathrm{i}}^{2}\right) \Phi(\delta)+\left(\sigma_{\mathrm{j}}^{2}+\mu_{\mathrm{j}}^{2}\right)(1-\Phi(\delta))+\left(\mu_{\mathrm{i}}+\mu_{\mathrm{j}}\right) \theta \varphi(\delta)-\mu_{\mathrm{k}}^{2}
$$

nilai minimum:

$$
\begin{gathered}
\mu_{\mathrm{k}}=\mu_{\mathrm{i}}(1-\Phi(\delta))+\mu_{\mathrm{j}} \Phi(\delta)-\theta \varphi(\delta) \\
\sigma_{\mathrm{k}}^{2}=\left(\sigma_{\mathrm{i}}^{2}+\mu_{\mathrm{i}}^{2}\right)(1-\Phi(\delta))+\left(\sigma_{\mathrm{j}}^{2}+\mu_{\mathrm{j}}^{2}\right) \Phi(\delta)-\left(\mu_{\mathrm{i}}+\mu_{\mathrm{j}}\right) \theta \varphi(\delta)-\mu_{\mathrm{k}}^{2}
\end{gathered}
$$

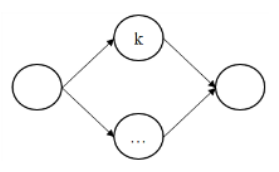

dimana:

$$
\delta=\frac{\mu_{\mathrm{i}}-\mu_{\mathrm{j}}}{\theta} ; \theta=\sqrt{\sigma_{\mathrm{i}}^{2}+\sigma_{\mathrm{j}}^{2}-2 \rho \sigma_{\mathrm{i}} \sigma_{\mathrm{j}}}
$$

(Sumber: Ballesteros-Pérez, 2017)

Nilai $\varphi(-)$ dan $\Phi(-)$ pada rumus jalur paralel merupakan nilai probability density function (PDF) dan cumulative distribution function (CDF). Nilai tersebut dapat dicari menggunakan grafik pada gambar 2. 


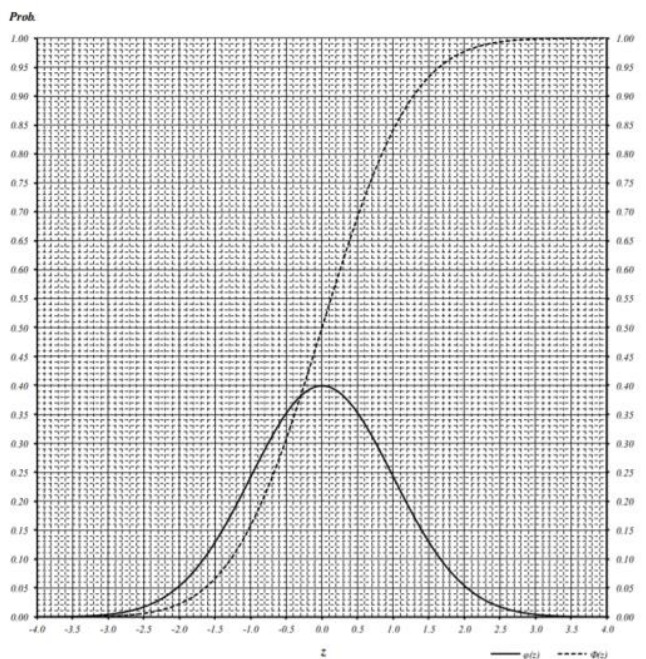

Gambar 2. Grafik probability density function $\varphi(\mathrm{z})$ dan cumulative distribution function $\Phi(\mathrm{z})$ dari standar distribusi normal

\section{Jaringan dengan korelasi antar aktivitas}

Terkadang ada jaringan kerja dimana proses merger berakhir pada node yang tidak dapat diuraikan. Ini terjadi ketika jalur paralel yang tidak bercabang dari node yang sama dan / atau tidak bertemu di node yang sama (Mehrotra et al., 1996 dalam Ballesteros-Pérez, 2017).

Dalam situasi seperti itu, jaringan yang ada dapat berakhir dalam sub jaringan. Untuk memecahkan sub jaringan, Mehrotra et al. (1996) dan Sculli dan Shum (1991) dalam Ballesteros-Pérez (2017), mengusulkan prosedur rekursif berurutan yang melibatkan menghitung semua varian dan nilai kovarian antara jalur terurai. Prosedur ini pada dasarnya memerlukan identifikasi semua jalur kemudian digabungkan satu per satu secara terpisah. Selanjutnya menggabungkan semua jalur yang terpisah menjadi satu. Tiap jalur diidentifikasi pada gambar 3, lalu dihitung semua varian dan kovarian antar jalur terurai pada tabel 3.

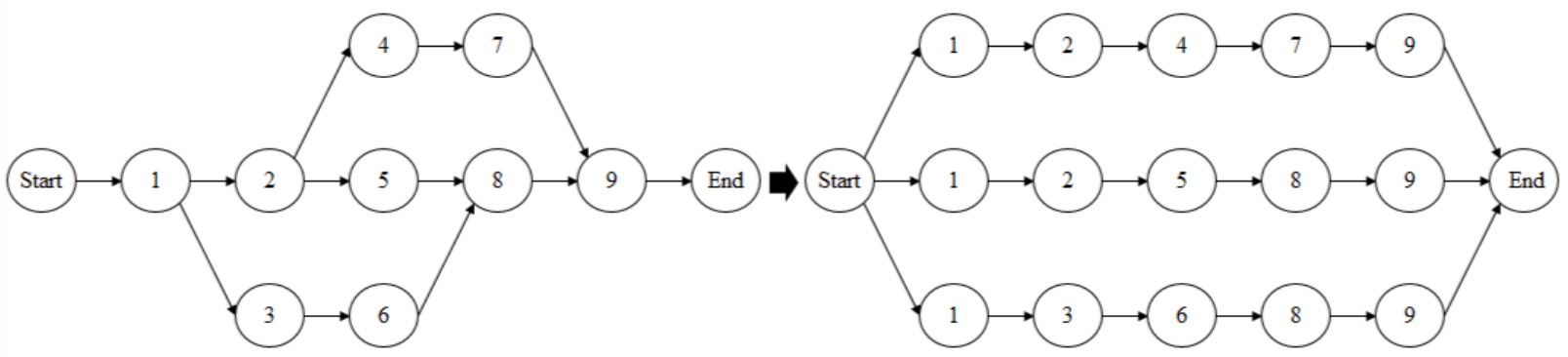

Gambar 3. Penguraian jalur tangled menjadi jalur terpisah

Tabel 3. Perhitungan varian dan kovarians tiap jalur

\begin{tabular}{|c|c|c|c|c|c|}
\hline Jalur & Kegiatan & $\mu_{\mathrm{k}}$ & A & B & $\mathrm{C}$ \\
\hline A & $1-2-4-7-9$ & $\begin{array}{c}\mu_{A}= \\
\mu_{1}+\mu_{2}+\mu_{4}+\mu_{7}+\mu_{9}\end{array}$ & $\begin{array}{c}\sigma^{2}{ }= \\
\sigma^{2}{ }_{1}+\sigma^{2}{ }_{2}+\sigma^{2}{ }_{4}+\sigma^{2}{ }_{7}+\sigma^{2}{ }_{9}\end{array}$ & $\begin{array}{c}\mathrm{COV}_{\mathrm{AB}}= \\
\sigma^{2}{ }_{1}+\sigma^{2}{ }_{2}+\sigma^{2}{ }_{9}\end{array}$ & $\begin{array}{c}\mathrm{COV}_{\mathrm{AC}}= \\
\sigma^{2}{ }_{1}+\sigma^{2}{ }_{9}\end{array}$ \\
\hline B & $1-2-5-8-9$ & $\begin{array}{c}\mu_{\mathrm{B}}= \\
\mu_{1}+\mu_{2}+\mu_{5}+\mu_{8}+\mu_{9}\end{array}$ & $\mathrm{COV}_{\mathrm{BA}}=\mathrm{COV}_{\mathrm{AB}}$ & $\begin{array}{c}\sigma^{2}{ }_{A}= \\
\sigma^{2}{ }_{1}+\sigma^{2}{ }_{2}+\sigma^{2}{ }_{5}+\sigma^{2}{ }_{8}+\sigma^{2}{ }_{9}\end{array}$ & $\begin{array}{c}\mathrm{COV} \mathrm{BC}_{\mathrm{BC}}= \\
\sigma^{2}{ }_{1}+\sigma^{2}{ }_{8}+\sigma^{2}{ }_{9}\end{array}$ \\
\hline $\mathrm{C}$ & $1-3-6-8-9$ & $\begin{array}{c}\mu_{\mathrm{C}}= \\
\mu_{1}+\mu_{3}+\mu_{6}+\mu_{8}+\mu_{9}\end{array}$ & $\mathrm{COV}_{\mathrm{CA}}=\mathrm{COV}_{\mathrm{AC}}$ & $\mathrm{COV}_{\mathrm{CB}}=\mathrm{COV}_{\mathrm{BC}}=$ & $\begin{array}{c}\sigma^{2}{ }_{\mathrm{A}}= \\
\sigma^{2}{ }_{1}+\sigma^{2}{ }_{3}+\sigma^{2}{ }_{6}+\sigma^{2}{ }_{8}+\sigma^{2}{ }_{9}\end{array}$ \\
\hline
\end{tabular}

Setelah semua nilai varians dan kovarians didapat, maka semua jalur yang terpisah dapat digabung menjadi satu, dengan nilai $\rho$ menggunakan persamaan: 


$$
\begin{gathered}
\rho_{\mathrm{AB}}=\frac{\operatorname{COV}_{\mathrm{AB}}}{\sigma_{\mathrm{A}} \sigma_{\mathrm{B}}} \\
\rho_{\mathrm{ABC}}=\frac{\operatorname{COV}_{\mathrm{AC}}+\Phi\left(\delta_{\mathrm{AB}}\right)+\operatorname{COV}_{\mathrm{BC}}\left[1-\Phi\left(\delta_{\mathrm{AB}}\right)\right]}{\sigma_{\mathrm{AB}} \sigma_{\mathrm{C}}} \\
\rho_{\mathrm{ABCD}}=\frac{\left\{\operatorname{COV}_{\mathrm{AD}} \Phi\left(\delta_{\mathrm{AB}}\right)+\operatorname{COV}_{\mathrm{BD}}\left[1-\Phi\left(\delta_{\mathrm{AB}}\right)\right]\right\} \Phi\left(\delta_{\mathrm{ABC}}\right)+\operatorname{COV}_{\mathrm{CD}}\left[1-\Phi\left(\delta_{\mathrm{ABC}}\right)\right]}{\sigma_{\mathrm{ABC}} \sigma_{\mathrm{D}}}
\end{gathered}
$$

dengan nilai $\mathrm{COV}=$ kovarians, $\sigma=$ standar deviasi.

\section{Simulasi Monte Carlo}

Monte Carlo adalah suatu teknik yang digunakan dalam mengambil keputusan berdasarkan simulasi statistik yang dilakukan secara berulang. Sumber penciptaan teknik berasal dari penelitian tentang pengembangan bom atom yang dilakukan selama Perang Dunia Kedua. Pada manajemen proyek, teknik Monte Carlo umumnya digunakan dalam memperkirakan risiko yang berhubungan dengan durasi dan biaya proyek (Wyrozębski dan Wyrozębska, 2013).

Simulasi Monte Carlo memungkinkan tidak hanya untuk menemukan waktu atau biaya proyek yang paling mungkin, tetapi juga untuk menghitung probabilitas terjadinya nilai yang diharapkan. Informasi yang didapat dari Monte Carlo sebenarnya tidak jauh berbeda dengan perencanaan PERT. Akan tetapi, simulasi Monte Carlo memperluas teknik PERT (Van Styke, 1963 dalam Wyrozębski dan Wyrozębska, 2013). Estimasi jadwal proyek atau biaya tidak didasarkan pada satu varian dari proyek (pada PERT, jalur kritis dihitung menurut durasi kegiatan yang diharapkan), tetapi menggunakan simulasi yang dilakukan berulang hingga 1.000, 10.000 atau lebih (Wyrozębski dan Wyrozębska, 2013).

Berikut langkah-langkah dari simulasi Monte Carlo dalam menentukan biaya dan durasi proyek (Pritchard, 2001):

1. Merumuskan area, ruang lingkup masalah dan tujuan analisis (misalnya untuk mengestimasi biaya proyek yang diperlukan);

2. Mengidentifikasi sumber data yang akan diteliti dan parameternya serta memperoleh data tersebut. Misalnya dalam mengestimasi distribusi probabilitas dari biaya pekerjaan, dapat diperoleh dari data historis dari proyek sebelumnya atau dari pakar;

3. Memodelan masalah yang dianalisis menggunakan software simulasi Monte Carlo simulasi, dan input data;

4. Menentuan parameter simulasi dengan melakukan repetisi dan iterasi sebanyak mungkin sesuai dengan kebutuhan simulasi;

5. Melakukan simulasi dengan menggunakan software dimana akan melakukan perhitungan secara otomatis dan acak;

6. Menganalisis data hasil simulasi software yang memperoleh nilai parameter dari distribusi variabel yang dihasilkan: jumlah repetisi, mean, standar deviasi, minimum, maksimum, median, nilai persentil dari distribusi. Informasi yang terkumpul berbentuk tabel atau dalam bentuk grafik (histogram).

\section{METODE PENELITIAN}

Diagram alir metode penelitian dapat dilihat pada gambar 4 dengan penjelasan tahapan sebagai berikut. Penelitian dimulai dengan pencarian dan pemilihan data proyek berupa jadwal rencana pelaksanaan proyek (Time Schedule) yang digunakan sebagai data penelitian. Proyek yang digunakan sebagai acuan penelitian merupakan proyek Marketing Gallery yang bertempat di kota Tangerang Selatan, Banten. 


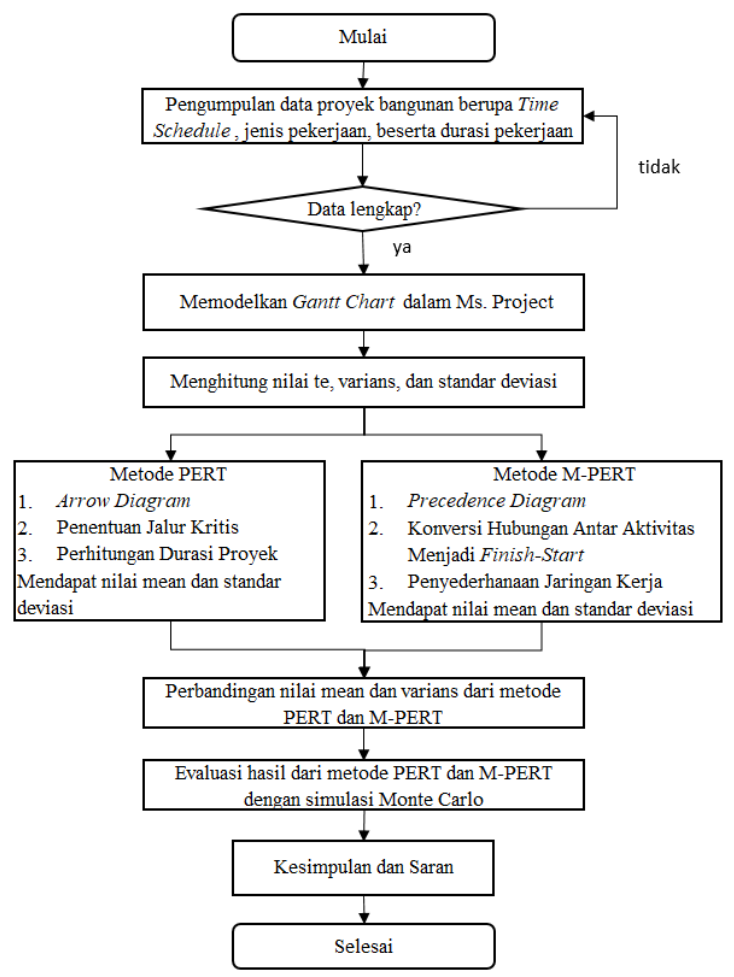

Gambar 4. Diagram alur penelitian

Data-data yang telah dikumpulkan kemudian diolah untuk penerapan metode PERT dan M-PERT. Hal pertama yang dilakukan adalah melakukan penyesuaian data-data yang diperlukan dalam metode PERT dan M-PERT. Kemudian menyusun tabel berisi item pekerjaan beserta durasi pekerjaan. Durasi pekerjaan yang digunakan adalah 3 perkiraan waktu, yaitu durasi optimis (a), durasi realistis (m), dan durasi pesimis (b). Durasi realistis didapatkan melalui data proyek yang ada, sedangkan data optimis dan pesimis didapatkan melalui konsultasi dengan narasumber di lapangan. Narasumber yang memberikan konsultasi merupakan Construction Manager pada proyek Marketing Gallery. Setelah menentukan tiga perkiraan waktu, selanjutnya dapat menghitung mean durasi (te), varians, dan standar deviasi untuk setiap pekerjaan.

Selanjutnya adalah menghitung durasi total proyek dengan metode PERT. Langkah-langkahnya sebagai berikut:

\section{Pembuatan Arrow Diagram / Activity on Arrow}

Data durasi dari tiap aktivitas disusun menjadi arrow diagram dengan hubungan antar aktivitas finish-start.

\section{Penentuan Jalur Kritis}

Mengidentifikasi aktivitas yang terletak pada jalur kritis. Jalur kritis diberikan warna yang berbeda pada jalurnya.

3. Perhitungan Durasi Proyek

Menghitung mean dan standar deviasi durasi proyek. Cara ini dilakukan dengan menjumlahkan mean dan standar deviasi aktivitas yang berada dalam jalur kritis.

Untuk metode M-PERT, berikut langkah-langkah untuk mendapatkan durasi total:

\section{Pembuatan Precedence Diagram / Activity on Node}

Data durasi dari masing-masing aktivitas dimodelkan menjadi precedence diagram.

\section{Konversi Hubungan Antar Aktivitas Menjadi Finish-Start}

Precedence diagram yang telah dimodelkan akan dikonversi menjadi precedence diagram dengan hubungan antar aktivitas finish-start. Hal itu dilakukan untuk memenuhi syarat metode M-PERT.

3. Penyederhanaan Jaringan Kerja 
Melakukan penggabungan aktivitas langkah demi langkah hingga tersisa satu aktivitas. Dalam melakukan penggabungan aktivitas, terdapat beberapa kondisi dalam melakukan merging seperti tabel 2. Dari hasil merging aktivitas akan didapat nilai mean dan varians durasi.

Setelah mendapatkan nilai mean durasi proyek dan standar deviasi dari kedua metode, Nilai tersebut dilakukan perbandingan menggunakan simulasi Monte Carlo.

\section{HASIL DAN PEMBAHASAN}

Data proyek yang didapatkan untuk penelitian ini berupa Time Schedule proyek, daftar pekerjaan beserta durasi pekerjaannya. Time Schedule yang didapatkan kemudian dimodelkan kedalam format Microsoft Project untuk menyederhanakan tampilan dalam penyajian data. Berikut pada gambar 5 merupakan penyajian jadwal pekerjaan proyek marketing gallery.

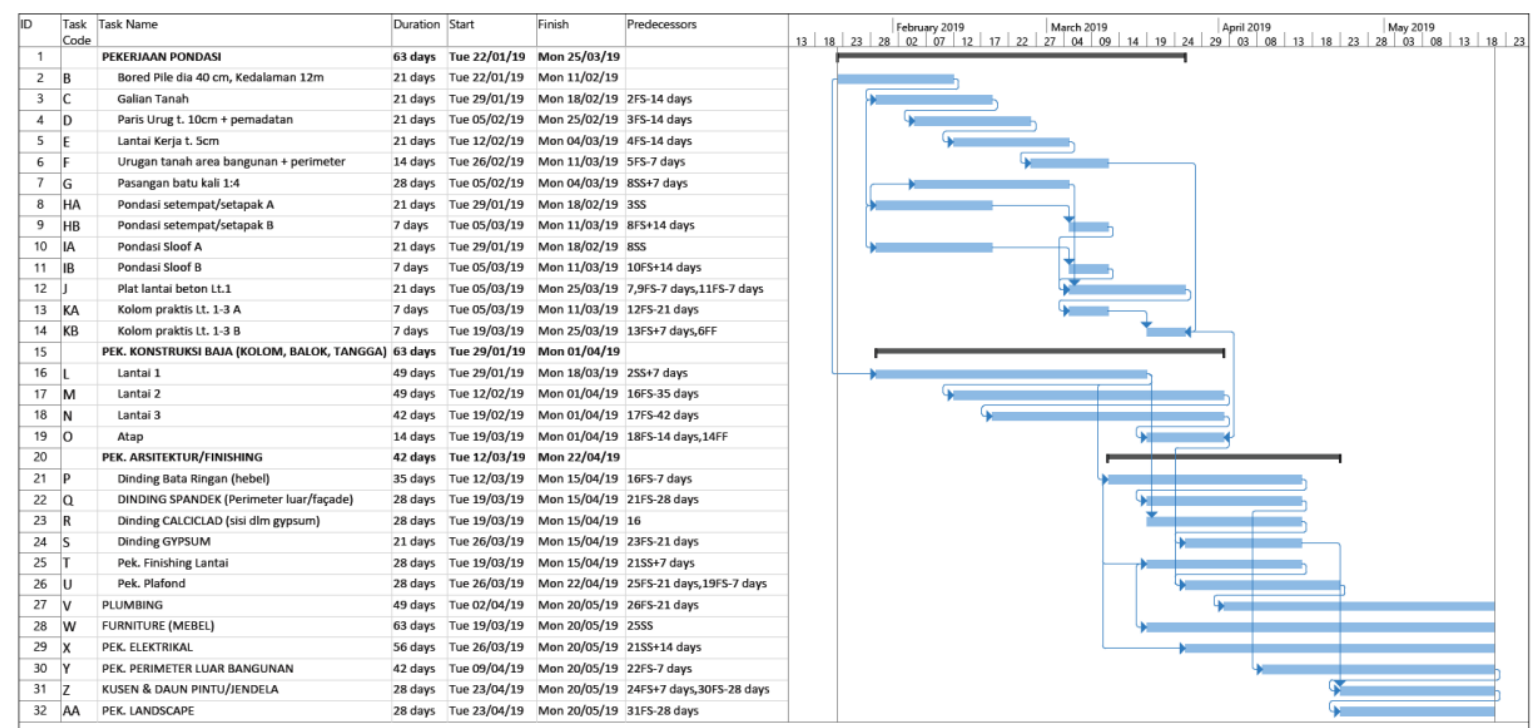

Gambar 5. Bar chart proyek marketing gallery

Dari daftar pekerjaan yang diperoleh, selanjutnya menentukan data durasi optimis, realistis, dan pesimis. Dari ketiga nilai durasi tersebut, dilakukan perhitungan untuk mendapatkan nilai te, varians, dan standar deviasi. Perhitungan tersebut dibuat seperti pada tabel 4 berikut ini.

Tabel 4. Daftar pekerjaan proyek marketing gallery

\begin{tabular}{|c|c|c|c|c|c|c|c|}
\hline \multirow{2}{*}{ Kode } & \multirow{2}{*}{ Jenis Pekerjaan } & \multicolumn{3}{|c|}{ Durasi (hari) } & \multirow{2}{*}{ Te } & \multirow{2}{*}{$\mathbf{S}$} & \multirow{2}{*}{$V(t e)$} \\
\hline & & a & $\mathrm{m}$ & $\mathrm{b}$ & & & \\
\hline & \multicolumn{7}{|l|}{ PEK. PONDASI } \\
\hline B & Bored pile dia. $40 \mathrm{~cm}$, Kedalaman $12 \mathrm{~m}$ & 14 & 21 & 30 & 21,33 & 2,67 & 7,11 \\
\hline $\mathrm{C}$ & Galian tanah & 10 & 21 & 28 & 20,33 & 3,00 & 9,00 \\
\hline $\mathrm{D}$ & Pasir urug t. $10 \mathrm{~cm}+$ pemadatan & 10 & 21 & 25 & 19,83 & 2,50 & 6,25 \\
\hline $\mathrm{E}$ & Lantai kerja t. $5 \mathrm{~cm}$ & 10 & 21 & 25 & 19,83 & 2,50 & 6,25 \\
\hline $\mathrm{F}$ & Urugan tanah area bangunan + perimeter & 10 & 14 & 21 & 14,50 & 1,83 & 3,36 \\
\hline $\mathrm{G}$ & Pasangan batu kali $1: 4$ & 14 & 28 & 35 & 26,83 & 3,50 & 12,25 \\
\hline HA & Pondasi setempat/setapak A & 14 & 21 & 28 & 21,00 & 2,33 & 5,44 \\
\hline $\mathrm{HB}$ & Pondasi setempat/setapak B & 3 & 7 & 7 & 6,33 & 0,67 & 0,44 \\
\hline IA & Pondasi Sloof A & 15 & 21 & 27 & 21,00 & 2,00 & 4,00 \\
\hline IB & Pondasi Sloof B & 5 & 7 & 8 & 6,83 & 0,50 & 0,25 \\
\hline $\mathrm{J}$ & Plat lantai beton Lt. 1 & 10 & 21 & 25 & 19,83 & 2,50 & 6,25 \\
\hline KA & Kolom praktis (area KM) 1t.1-3 A & 5 & 7 & 10 & 7,17 & 0,83 & 0,69 \\
\hline \multirow[t]{2}{*}{$\mathrm{KB}$} & Kolom praktis (area KM) 1t.1-3 B & 5 & 7 & 10 & 7,17 & 0,83 & 0,69 \\
\hline & $\begin{array}{l}\text { PEK. KONSTRUKSI BAJA (Kolom, } \\
\text { Balok,Tangga) }\end{array}$ & & & & & & \\
\hline $\mathrm{L}$ & Lantai 1 & 35 & 49 & 56 & 47,83 & 3,50 & 12,25 \\
\hline M & Lantai 2 & 35 & 49 & 56 & 47,83 & 3,50 & 12,25 \\
\hline $\mathrm{N}$ & Lantai 3 & 28 & 42 & 56 & 42,00 & 4,67 & 21,78 \\
\hline $\mathrm{O}$ & Atap & 10 & 14 & 20 & 14,33 & 1,67 & 2,78 \\
\hline
\end{tabular}


Tabel 4. Daftar pekerjaan proyek marketing gallery (lanjutan)

\begin{tabular}{clrrrrrr}
\hline & PEK. ARSITEKTUR/ FINISHING & & & & & & \\
\hline P & Dinding Bata Ringan (hebel) & 20 & 35 & 40 & 33,33 & 3,33 & 11,11 \\
Q & Dinding Spandek (Perimeter luar/façade) & 20 & 28 & 35 & 27,83 & 2,50 & 6,25 \\
R & Dinding Calciclad (sisi dlm gypsum) & 20 & 28 & 35 & 27,83 & 2,50 & 6,25 \\
S & Dinding Gypsum & 14 & 21 & 30 & 21,33 & 2,67 & 7,11 \\
T & Pek. Finishing Lantai & 16 & 28 & 34 & 27,00 & 3,00 & 9,00 \\
U & Pek. Plafond & 20 & 28 & 34 & 27,67 & 2,33 & 5,44 \\
\hline V & PLUMBING & 31 & 49 & 56 & 47,17 & 4,17 & 17,36 \\
W & FURNITURE (MEBEL) & 48 & 63 & 90 & 65,00 & 7,00 & 49,00 \\
X & PEK. ELEKTRIKAL & 44 & 56 & 66 & 55,67 & 3,67 & 13,44 \\
Y & PEK. PERIMETER LUAR BANGUNAN & 30 & 42 & 52 & 41,67 & 3,67 & 13,44 \\
Z & KUSEN \& DAUN PINTU/JENDELA & 20 & 28 & 35 & 27,83 & 2,50 & 6,25 \\
AA & PEK. LANDSCAPE (depan \& belakang MG) & 14 & 28 & 36 & 27,00 & 3,67 & 13,44 \\
\hline
\end{tabular}

\section{Durasi total proyek dari Metode PERT}

Dari waktu te dan standar deviasi tiap pekerjaan yang telah didapat pada tabel 3, selanjutnya dibuat diagram kerja Activity on Arrow (AoA) untuk menentukan jalur kritis. Penentuan jalur kritis berguna untuk menentukan durasi proyek total beserta standar deviasinya. Dari hasil analisis jalur kritis, didapatkan 5 pekerjaan kritis, yaitu pada pekerjaan B1 - L1 - L2 - P1 - W seperti yang terlihat pada tabel 5 berikut.

Tabel 5. Daftar pekerjaan pada lintasan kritis

\begin{tabular}{clc}
\hline Kode & \multicolumn{1}{c}{ Pekerjaan pada Lintasan Kritis } & S \\
\hline B1 & Bored pile (Bagian 1) & 0,000 \\
L1 & Lantai 1 (Bagian 1) & 0,000 \\
L2 & Lantai 1 (Bagian 2) & 0,000 \\
P1 & Dinding Bata Ringan (Bagian 1) & 0,000 \\
W & Furniture (Mebel) & 7,000 \\
\hline
\end{tabular}

Dari kelima pekerjaan pada lintasan kritis, didapat durasi proyek total sebesar 121 hari dengan nilai standar deviasi 7,000

\section{Durasi total proyek dari Metode M-PERT}

Berbeda dengan metode PERT, metode M-PERT menggunakan diagram kerja Activity on Node (AoN). Pada metode M-PERT, semua hubungan pekerjaan harus dalam bentuk Finish-to-Start, oleh karena itu segala jenis hubungan precedence selain Finish-to-Start harus dikonversi sesuai dengan tabel 1. Berikut model diagram kerja AoN proyek Marketing Gallery pada gambar 6.

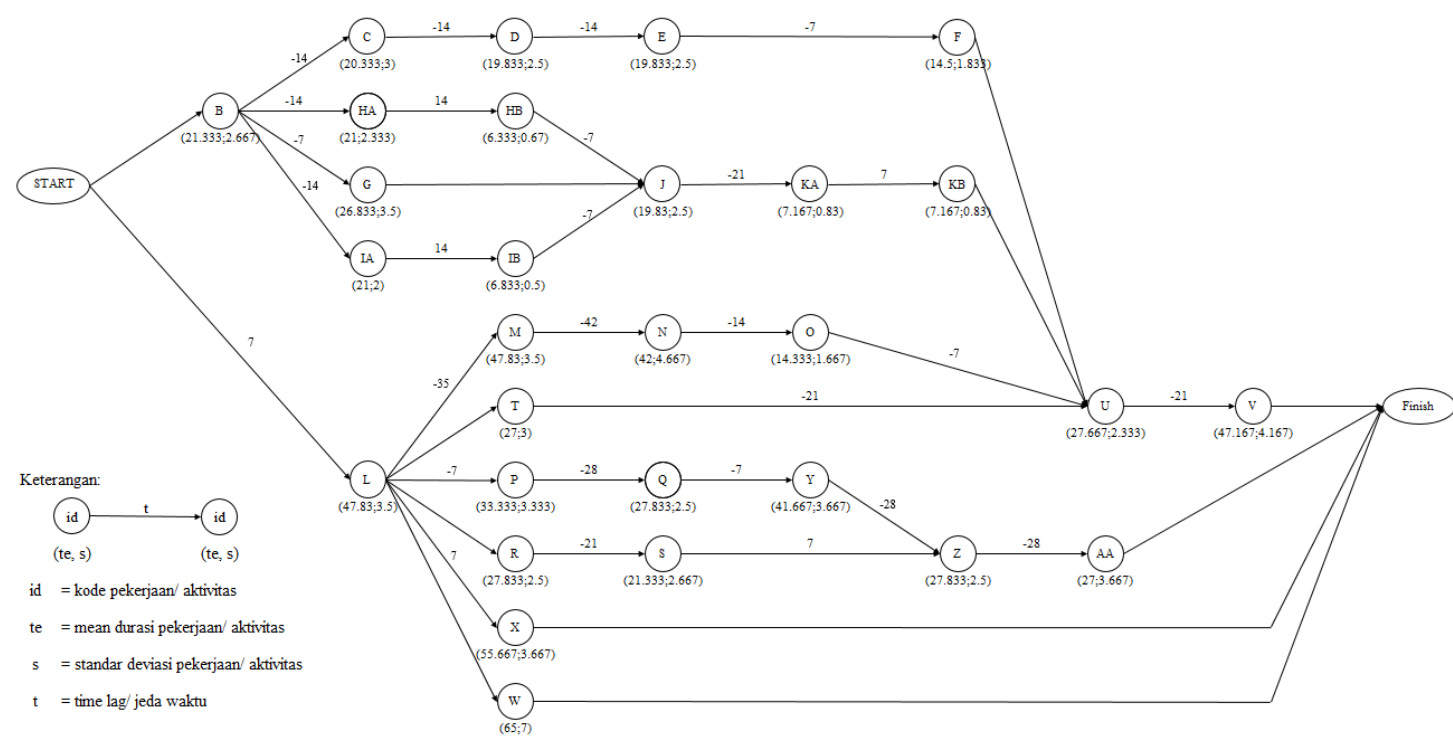

Gambar 6. Diagram jaringan kerja Activity on Node proyek Marketing Gallery 
Setelah diagram jaringan kerja terbentuk, maka selanjutnya adalah memulai proses penggabungan antar pekerjaan (merging) langkah demi langkah. Berikut step-by-step penggabungan untuk mendapatkan durasi total proyek pada gambar 7 .
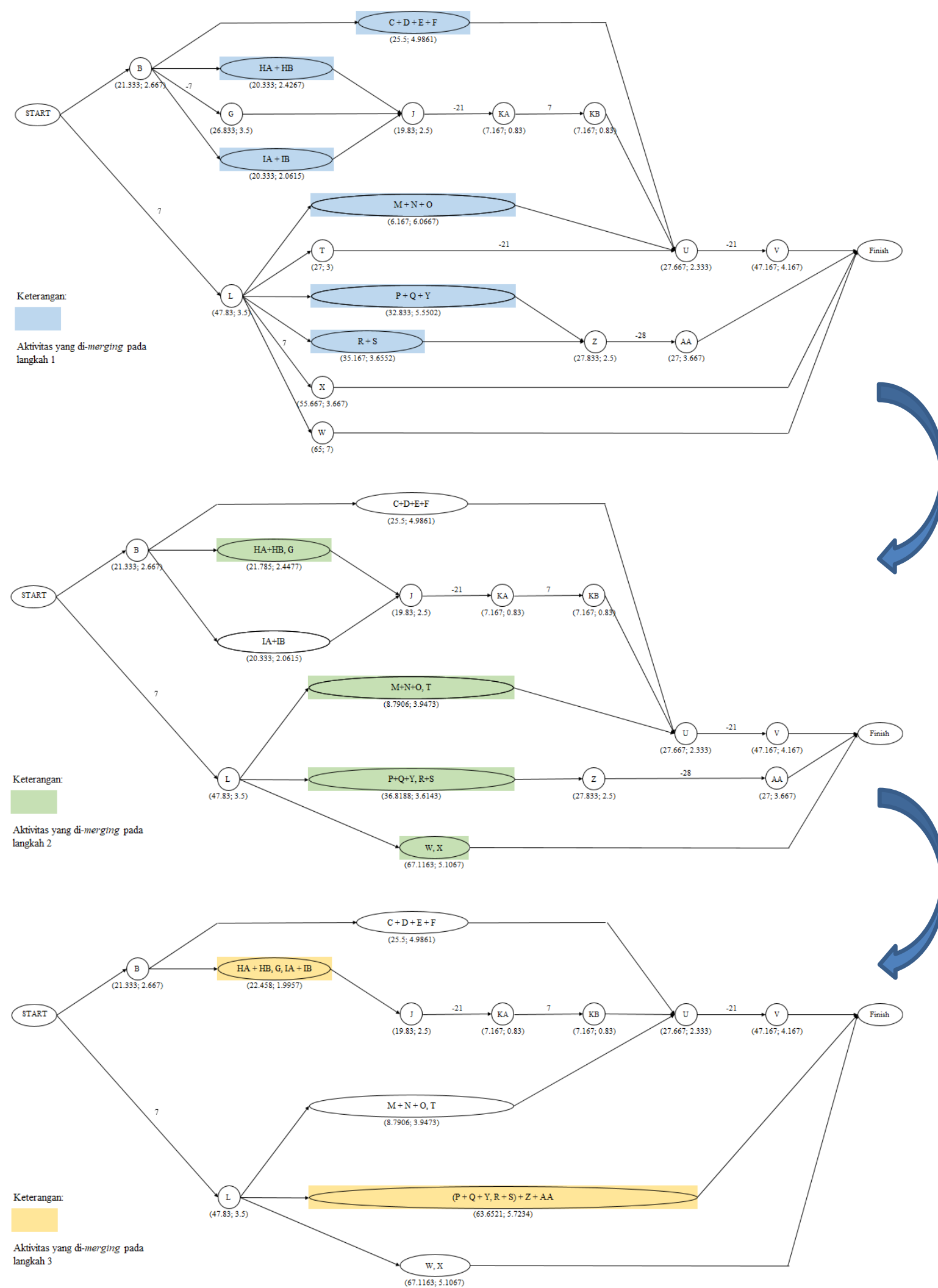

Gambar 7. Langkah penggabungan jaringan kerja 

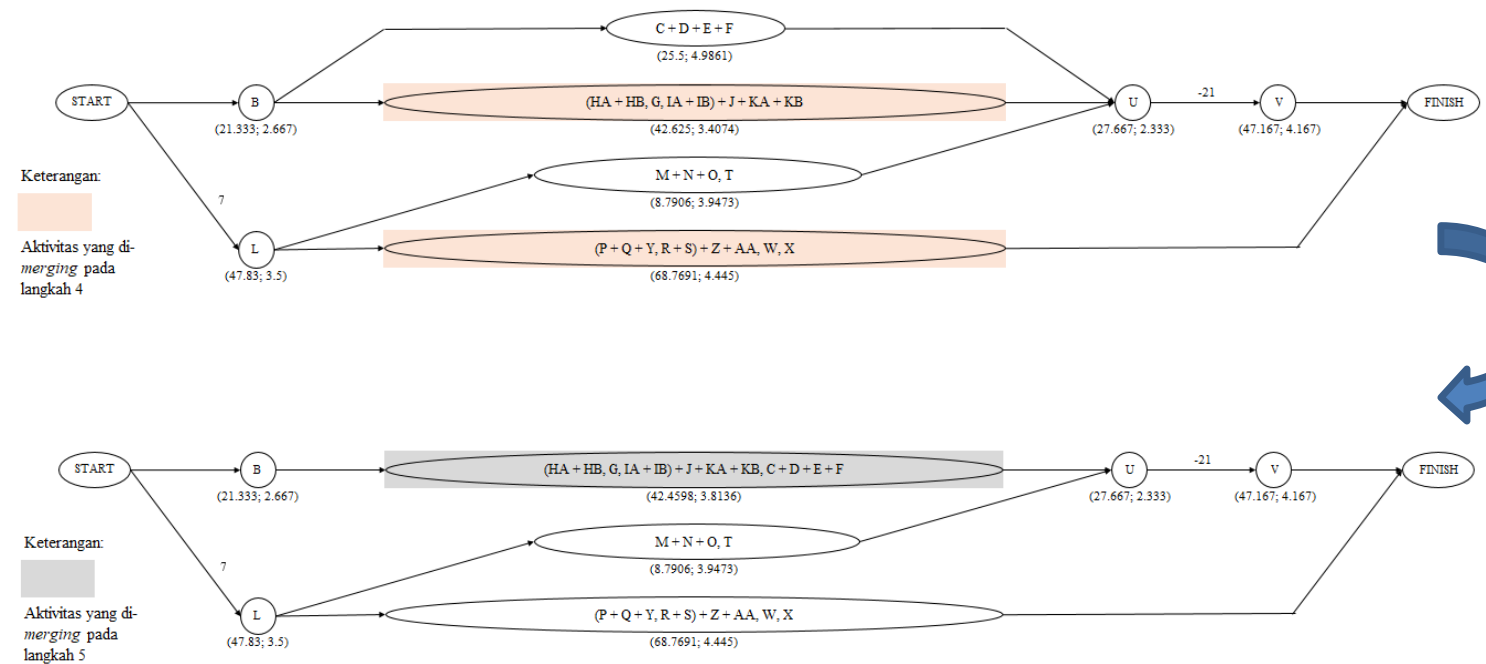

Gambar 7. Langkah penggabungan jaringan kerja (lanjutan)

Pada langkah terakhir, lintasan-lintasan pada jaringan kerja tersebut perlu diuraikan satu per satu sebagai lintasan yang berdiri sendiri. Setelah menguraikan lintasan satu per satu, hal yang perlu dilakukan adalah menentukan mean durasi dan varians dari tiap lintasan serta nilai kovarians antar lintasan yang terurai. Selanjutnya lintasan yang terurai digabung menjadi satu seperti pada gambar 8 .

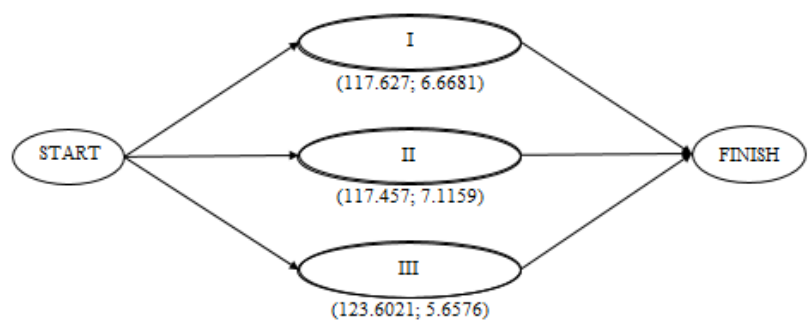

Gambar 8. Jaringan kerja yang telah terurai

Setelah itu, penggabungan aktivitas dilakukan seperti biasa hingga akhirnya didapatkan hanya tersisa satu pekerjaan tersisa dengan durasi total proyek dan standar deviasinya. Durasi total proyek yang didapatkan dari metode M-PERT adalah 125,344 hari dengan standar deviasi sebesar 5,0791. Hasil akhir jaringan kerjanya dapat dilihat pada gambar 9.

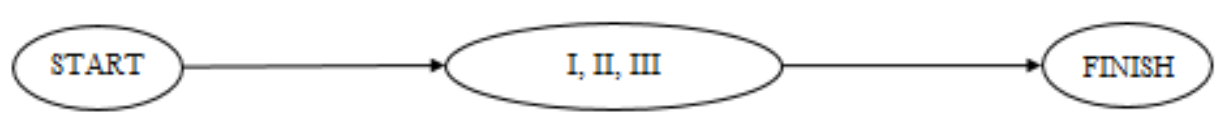

(125.344; 5.0791)

Gambar 9. Hasil akhir penggabungan jaringan kerja pada metode M-PERT

\section{Durasi total proyek dengan simulasi Monte Carlo menggunakan program komputer}

Durasi proyek dan standar deviasi yang didapatkan dari metode PERT dan M-PERT akan dibandingkan dengan simulasi Monte Carlo dengan program komputer. Program yang digunakan dalam penelitian ini adalah Full Monte 2017 yang merupakan program external dari Ms. Project.

Untuk dapat melakukan simulasi, diperlukan data input berupa durasi optimis (a), durasi realistis (m), dan durasi pesimis (b) dari masing-masing pekerjaan. Setelah semua data telah di-input, tentukan jumlah iterasi yang diinginkan, lalu lalu jalankan simulasi. 
Hasil dari simulasi ditampilkan berupa grafik histogram beserta kurva distribusi kumulatif yang dapat dilihat pada gambar 10. Pada gambar juga tertera mean durasi proyek dan juga standar deviasinya.

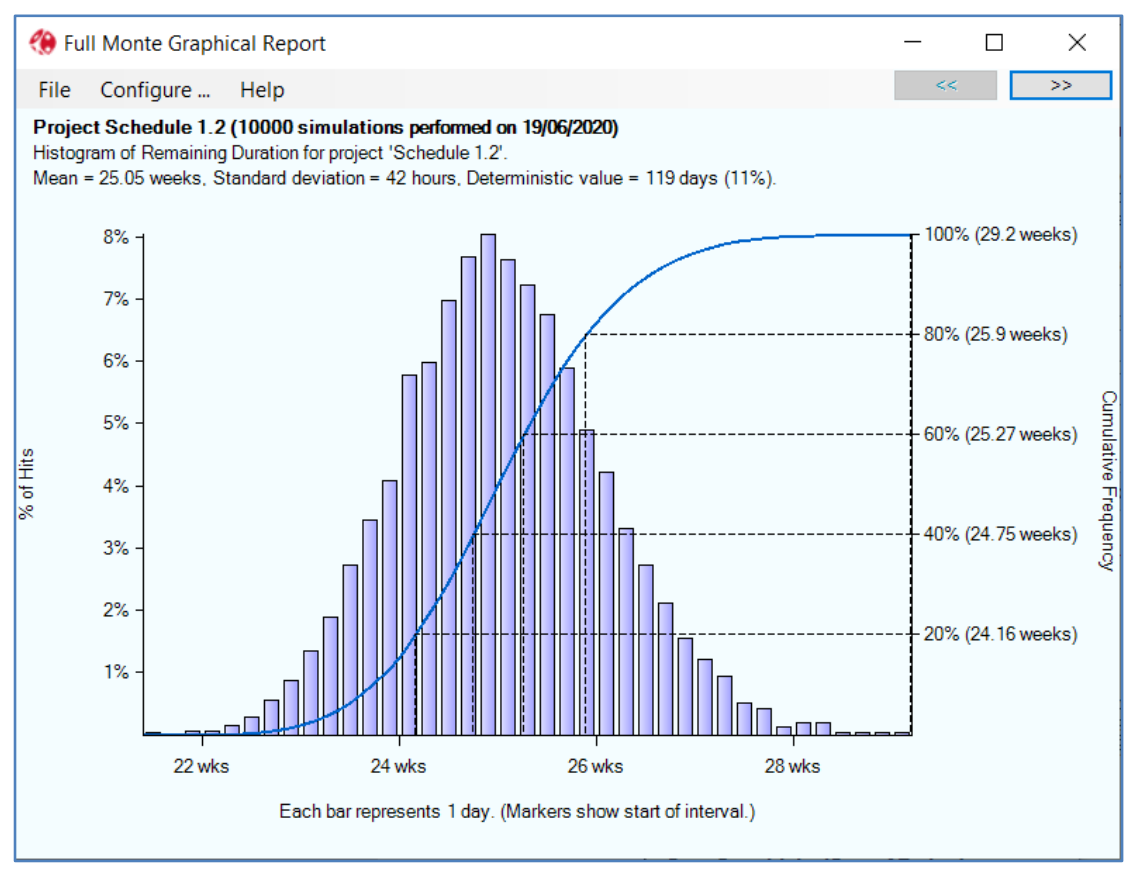

Gambar 10. Hasil simulasi Monte Carlo pada program Full Monte

Hasil pada simulasi memberikan durasi total proyek sebesar 25,05 minggu atau 125,25 hari (1 minggu = 5 hari kerja) dengan nilai standar deviasi sebesar 42 jam atau 5,25 hari ( 1 hari $=8$ jam kerja). Pada gambar 14 , juga dapat dilihat durasi terpendek pada proyek ini adalah 21,4 minggu atau 107 hari dan durasi terpanjang pada ini adalah 29,2 minggu atau 146 hari.

Setelah mendapat durasi total proyek dan standar deviasi dari hasil simulasi komputer, selanjutnya dapat membuat perbandingan distribusi kumulatif antara metode PERT, metode M-PERT, dan hasil simulasi komputer. Perbandingan distribusi kumulatif dapat dibuat dalam Microsoft Excel menggunakan fungsi "=NORM.DIST(x, mean, standar_deviasi, kumulatif)". X merupakan durasi proyek yang ditinjau, sedangkan mean dan standar deviasi merupakan durasi proyek dan standar deviasi dari masing-masing metode. Nilai X yang digunakan adalah rentang waktu durasi terpendek dan terpanjang dari hasil simulasi komputer yaitu 107 hari - 146 hari. Kurva distribusi kumulatif dari ketiga metode dimodelkan dalam gambar 11.

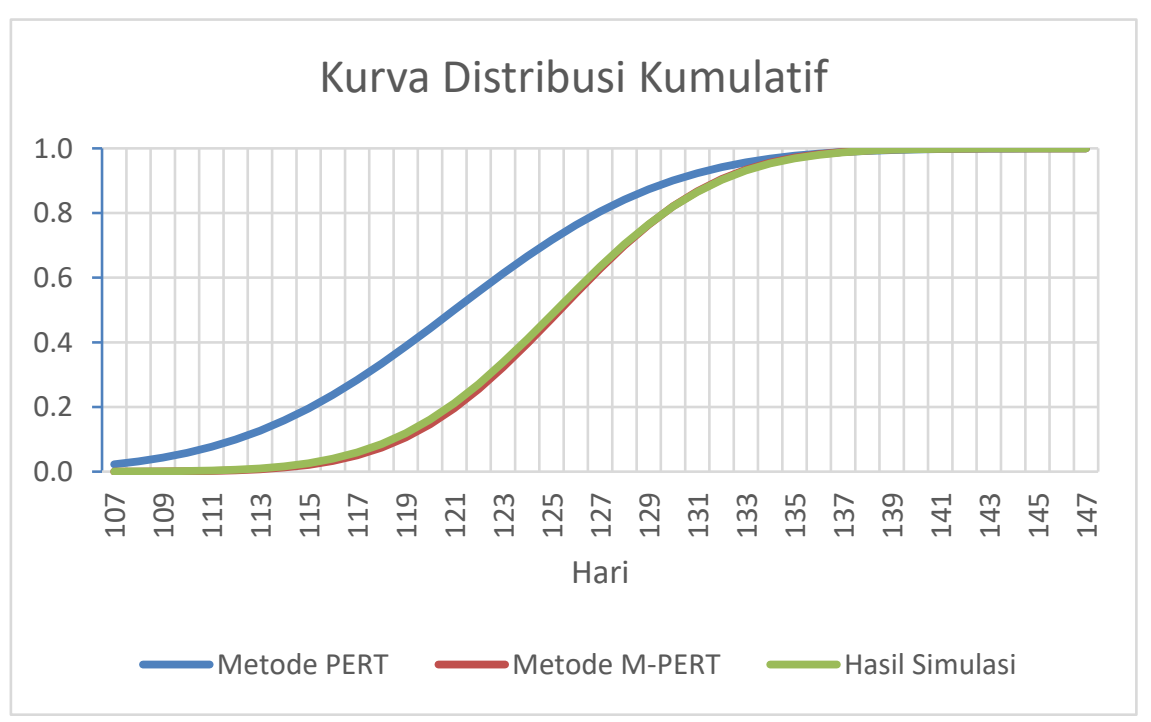

Gambar 11. Kurva distribusi kumulatif dari metode PERT, M-PERT, dan hasil simulasi 


\section{KESIMPULAN DAN SARAN}

\section{Kesimpulan}

Kesimpulan yang diperoleh dari penelitian pada proyek Marketing Gallery adalah:

Perbandingan hasil mean durasi dan standar deviasi proyek secara keseluruhan antara metode PERT dan metode MPERT:

1. Mean durasi proyek secara keseluruhan dari metode PERT adalah 121 hari, sedangkan mean durasi proyek secara keseluruhan dari metode M-PERT adalah 125,344 hari.

2. Standar deviasi yang diperoleh dari metode PERT sebesar 7,00, sedangkan standar deviasi yang diperoleh dari metode M-PERT sebesar 5,079.

3. Hal ini menunjukan metode M-PERT memberikan hasil yang lebih akurat disertai dengan lebih panjangnya durasi proyek. Panjangnya durasi proyek disebabkan oleh banyaknya penggabungan pekerjaan pada satu node.

Perbandingan hasil mean durasi dan standar deviasi proyek secara keseluruhan antara metode PERT, metode MPERT dan simulasi Monte Carlo menggunakan Microsoft Project:

1. Mean durasi proyek secara keseluruhan dari hasil simulasi Monte Carlo adalah 125,2 hari dan standar deviasi yang diperoleh sebesar 5,25.

2. Jika dibandingkan dengan hasil pada metode PERT dan M-PERT, dapat dilihat bahwa hasil metode M-PERT memberikan selisih yang lebih kecil terhadap hasil simulasi daripada metode PERT. Sehingga metode MPERT dapat memberikan hasil yang lebih mendekati dengan simulasi komputer.

\section{Saran}

Saran yang dapat diberikan dari penelitian ini adalah:

1 Dari ketiga metode tersebut, perhitungan durasi proyek ini disarankan menggunakan simulasi Monte Carlo karena metode ini memberikan durasi proyek yang lebih cepat disertai dengan standar deviasi yang tidak jauh berbeda dengan metode M-PERT.

2 Penelitian ini hanya dilakukan pada proyek gedung tiga lantai. Untuk meningkatkan validitas dan keakuratan dalam menggunakan metode M-PERT, perlu memperbanyak penelitian-penelitian yang lebih lanjut pada metode M-PERT, khususnya pada proyek gedung bertingkat tinggi.

\section{DAFTAR PUSTAKA}

Ballesteros-Pérez, Pablo. "M-PERT: Manual Project-Duration Estimation Technique." Journal Construction Engineering and Management (2017).

Heizer, Jay and Barry Render. Operation Management. 9th. Vol. 1. Jakarta: Salemba Empat, 2005.

PMI (Project Management Institute). A guide to the project management body of knowledge (PMBOK Guide). 6th. Newtown Square, PA, 2017.

Pritchard, C L. Risk Management, Concepts and Guidance. ESI International, 2001.

Siswanto. Operation Research Jilid II. Jakarta: Erlangga, 2007.

Soeharto, Imam. Manajemen Proyek (Dari Konseptual Sampai Operasional) Jilid I. Edisi Kedua. Jakarta: Erlangga, 1999.

Wyrozębski, Paweł dan Agnieszka Wyrozębska. "Challenges of project planning in the probabilistic approach using PERT, GERT.” Journal of Management and Marketing 1.1 (2013): 1-8. 
